\title{
Trwałość przemysłowo-osadniczych układów przestrzennych w starym rejonie przemyslowym (przykład dorzecza Malej Panwi)
}

Przedstawiona praca nawiązuje tematycznie i przestrzennie do wczesnej pracy autora o rozwoju ośrodków przemysłowych nad Małą Panwią (Rajman, 1962). Praca ta reprezentowała częsty jeszcze wówczas w geografii przemysłu kierunek historyczno-geograficzny (Kortus, Pakuła, 1998), zwany także retrospektywnym (Misztal, Zioło, 1998). Istotą tego nurtu było badanie uwarunkowań rozwoju przemysłu, a w szczególności podjęcie prób ukazania zmiany roli poszczególnych czynników lokalizacyjnych w czasie. W pracach takich uwzględniało się zatem zazwyczaj historyczne warunki powstania, czynniki lokalizacyjne oraz rozwój, rozmieszczenie zakładów przemysłowych, a także kształtowanie się struktury przestrzennej przemysłu. Takie, po części krajobrazowe ujmowanie problematyki przemysłowej, poparte bezpośrednimi badaniami terenowymi, wynikało w znacznym stopniu z ówczesnego braku publikowanej bazy statystycznej, nie tylko zresztą odnoszącej się do zagadnień przemysłowych.

We wspomnianym opracowaniu, które terytorialnie obejmowało jedynie „opolskostrzelecki” fragment dorzecza Małej Panwi, zwrócono uwagę nie tylko na formowanie się skupień i ośrodków przemysłowych, głównie hutniczych, lecz także na rolę wczesnego uprzemysłowienia w przekształcaniu środowiska geograficznego, na znaczenie przemysłu w procesach osiedlotwórczych oraz w kształtowaniu struktury społeczno-zawodowej mieszkańców. Faktyczny obszar XVIII i XIX-wiecznego hutnictwa żelaza rozciagał się jednak znacznie dalej, w górę dorzecza Małej Panwi, obejmując $\mathrm{z}$ jednej strony terytorium dzisiejszych Kalet (w 1789 r. w tamtejszym wielkim piecu zastosowano doświadczalnie koks zamiast węgla drzewnego) i granicznej doliny Liswarty (ostatnią kuźnicę we wschodniej części dorzecza Małej Panwi, w Bruśku w gm. Koszęcin, unieruchomiono dopiero w 1890 r.), z drugiej zaś sięgał na północ od wspomnianego dorzecza, na teren dzisiejszych powiatów kluczborskiego i oleskiego. Do połowy XIX w. funkcjonowało tam wiele małych kopalń rud żelaza i kuźnic, a jedna $\mathrm{z}$ hut $\mathrm{z}$ wielkim piecem na węgiel drzewny przetrwała w Krzyżańcowicach k/Gorzowa Śl. aż do 1911 r.

Jak pokazały cytowane studia, oparte $\mathrm{z}$ jednej strony na pruskich i niemieckich statystykach, literaturze historycznej oraz źródłach kartograficznych, z drugiej zaś na dobrej znajomości terenu badań $\mathrm{z}$ autopsji, przemysł, a przede wszystkim hutnictwo żelaza, bazujące do połowy XIX w. na miejscowych rudach limonitowych i darniowych oraz na bogactwie lasów i rzek, doprowadził do istotnych zmian w krajobrazie. Do dziś zachowały się 
na omawianym obszarze liczne polany śródleśne, różnego rodzaju budowle hydrotechniczne, jak jazy, kanały, pozostałości wodnych kół napędowych itp. urządzeń. Jeszcze większe były prawdopodobnie przeobrażenia w sieci osadniczej, słabo do tego czasu zaludnionego regionu. Stary przemysł hutniczy i towarzyszące mu zakłady był bowiem podstawowym czynnikiem osiedlotwórczym dla czterech dzisiejszych miast omawianego regionu.

Zalążkiem tych wczesnych procesów osadniczych, związanych z wykorzystaniem czynnika uprzemysłowienia była tzw. kolonizacja fryderycjańska (nazwana tak od króla pruskiego Fryderyka II, czyli Wielkiego), szeroko opisywana w literaturze historycznej, słabiej natomiast uwzględniana w opracowaniach geograficznych. Była to jednak przede wszystkim osadnicza akcja germanizacyjna, prowadzona w latach 1741-1805, z głównym nasileniem przypadającym na okres 1770-86. Akcja ta polegała na zakładaniu licznych kolonii rolniczych oraz śródleśnych osad rzemieślniczych i górniczo-hutniczych i swym zasięgiem terytorialnym obejmowała prawie puste do tego czasu obszary leśne Górnego Śląska, w tym również interesujące nas tu dorzecza Małej Panwi i lewobrzeżnych dopływów Stobrawy (Bogacicy i Budkowiczanki z Brynica). W dnie dolin tych rzek widoczne są nadal ślady starych koryt, głównie dawnych młynówek i kanałów doprowadzających wodę do licznych kuźnic. Jednym z silnie do dziś zaznaczonych w krajobrazie jest suche koryto starego 8,5 km kanału, który prowadził od XVIII-wiecznej sluzy „Malapartus” na Małej Panwi w pobliżu Zawadzkiego (urządzenie jej zdewastowane po II wojnie, dziś oczywiście już nie funkcjonuje) do niewielkiej huty żelaza w Kolonowskiem, zbudowanej w $1780 \mathrm{r}$. przez hr. Filipa Collonę ze Strzelc Opolskich, a czynnej do 1927 r. Drugi, podobny kanał, doprowadzał wodę ze spiętrzenia na Małej Panwi w Żędowicach do huty żelaza w Zawadzkiem (kanał ten, jak i znajdujący się przed hutą staw, zachowały się do dzisiaj, a napęd parowy w młotowni dawnej huty „Andrzej” zastąpiono elektrycznym dopiero pod koniec lat 50-tych XX w.). O historii starej huty w Ozimku jako zakładu wielkopiecowego świadczy do dziś zachowana potężna hałda żużlowa, w większości porośnięta już trawą i krzewami. Swego rodzaju ciekawostką techniczną, a zarazem reliktem dawnej techniki hutniczej, jest także stalowy most wiszący nad kanałem doprowadzającym niegdyś wodę z Małej Panwi do urządzeń hutniczych. Zbudowany w tamtejszej hucie w 1827 r. jest bowiem najstarszą tego typu, zachowaną konstrukcją mostową w Europie. Wymieniając w tym miejscu tylko kilka przykładów dawnych urządzeń technicznych należałoby równocześnie wyrazić nadzieję, że utworzenie w ostatnim czasie dwóch parków krajobrazowych „Bory Stobrawskie” i „Lasy nad górną Liswartą” przyczyni się także do utrwalenia w krajobrazie północnej i wschodniej części tego starego rejonu hutniczego różnych reliktów dawnego uprzemysłowienia.

Jak pokazaly studia toponomastyczne prof. H. Borka (1989), a także wcześniejsze T. Ładogórskiego (1949), w wyniku szeroko zakrojonej akcji kolonizacji fryderycjańskiej powstało na obszarze Górnego Śląska ponad 200 regularnych kolonii, w tym około 60 na interesującym nas obszarze dorzecza Małej Panwi. Były to przede wszystkim niewielkie osady drwali, smolarzy, węglarzy, hutników szkła oraz pracowników licznych w dorzeczach Małej Panwi i Stobrawy kuźnic. Tych ostatnich osad było prawdopodobnie 15. Wiele $\mathrm{z}$ tych kolonii wtopiło się z biegiem lat $\mathrm{w}$ istniejącą już wcześniej sieć osadniczą, zrastając się z sąsiednimi wsiami, część przekształciła się w samodzielne ogniwa, tworząc zalążki przyszłych osiedli i miast przemysłowych (Kalety, Ozimek, Zawadzkie, Kolonowskie), 
inne zaś zanikły w przestrzeni, pozostając jedynie w zapisach źródłowych, czasem także w zachowanej ikonografii z XVIII i XIX stulecia.

To krótkie wprowadzenie historyczne stanowi podstawę dalszych rozważań skoncentrowanych juź głównie na osadniczych reliktach dawnego uprzemysłowienia. Należy zatem postawić pytanie, czy i w jakich formach XVIII i XIX-wieczne hutnictwo i związane z nim zakłady przemysłowe przetrwały w sieci osadniczej i krajobrazie dorzecza Małej Panwi i Stobrawy? Na czym polega współczesna rola tego przemysłu w strukturze sieci osadniczej? Czy stary ten rejon hutniczy można jeszcze nazwać obszarem przemysłowym?

Charakteryzowany obszar stanowi dziś klasyczne pogranicze dwóch regionów administracyjno-gospodarczych, jakimi są województwa opolskie i śląskie, wchodząc w skład aż siedmiu powiatów. Historyczny obszar dorzecza Małej Panwi i lewobrzeźnej części dorzecza Stobrawy, o łącznej powierzchni $2.520 \mathrm{~km}^{2}$, podzielony jest między 21 gmin, spośród których 7 to gminy miejsko-wiejskie. Z liczbą 213 tys. mieszkańców jest to jednak w warunkach śląskich nadal słabo zaludniony obszar, gdyż na $1 \mathrm{~km}^{2}$ powierzchni (w znacznej części zalesionej) przypada tu tylko 85 osób (przy średniej dla woj. opolskiego 115 osób i śląskiego 396 osób na $\mathrm{km}^{2}$ ). Także poziomem urbanizacji charakteryzowany obszar odbiega bardzo wyraźnie od regionu górnośląskiego. Ludność miejska stanowi tu bowiem tylko 32,6\% ogółu mieszkańców, skupiając się w sześciu małych miastach i jednym ośrodku średniej wielkości (powiatowy Lubliniec w woj. śląskim, liczący 27,1 tys. mieszkańców, położony jest już właściwie na umownej granicy omawianego obszaru przemysłowego). Jak jednak większość terenów Górnego Sląska, tak i obszar dorzecza Małej Panwi i lewobrzeżnej Stobrawy zamieszkały jest głównie przez ludność utrzymującą się z zajęć nierolniczych. Zjawiskiem powszechnym jest tu bowiem tzw. semiurbanizacja, szerzej ukazana m.in. przez prof. S. Golachowskiego z ośrodka wrocławskiego, która w dużym stopniu nawiązuje też do sygnalizowanych wyżej tradycji uprzemysłowienia (Golachowski, 1965). W tutejszych hutach pracują kolejne pokolenia dawnych kuźników, w okolicach Ozimka jest to juź ósme pokolenie, w rejonie zaś Zawadzkiego szósta generacja hutników. Warto wspomnieć, że już 30 lat temu opolski historyk Augustyn Wajda odtwarzał te tradycje w swej interesującej pracy doktorskiej pt. „Przemiany społecznej atrakcyjności starego ośrodka przemysłowego w środowisku wiejskim (na przykładzie Huty Małapanew w Ozimku)" (Wajda, 1970), ukazując m.in. rolę tego zakładu jako swoistej kuźni kadr hutniczych dla okręgu górnośląskiego.

Z dawnych zakładów hutniczych, licznie występujących tu jeszcze w połowie XIX w., przetrwały jedynie dwa. Huta „Małapanew” w Ozimku, założona w 1753 r. jako huta królewska, z wielkim piecem, wytwórnią uzbrojenia dla pruskiej armii i fabryką maszyn, jest dziś jednym z największych w kraju producentów odlewów staliwnych, walców hutniczych i armatury okrętowej, współpracując od lat 70-tych XX w. z „Hutą Katowice”. Przy hucie „Małapanew” znajduje się również duża Wytwórnia Gazów Technicznych, a z procesem hutniczym kooperuje kilka firm metalowo-konstrukcyjnych, wyrosłych w trakcie prywatyzacji macierzystego zakładu. Do największych z nich należą: "Armatura”, "Maszyny i konstrukcje" oraz „Modelarnia", dziś spółki z o.o., które w swych nazwach zachowały historyczne określenie „Małapanew”.

Drugą z zachowanych hut żelaza jest Huta „Andrzej” w Zawadzkiem. Założona w 1836 r. jako huta prywatna hr. Andrzeja Renarda ze Strzelc Opolskich (w latach 1954-90 znana była jako Huta im. gen. K. Świerczewskiego), nie posiadała nigdy wielkiego pieca 
(opalany węglem drzewnym wielki piec funkcjonował jeszcze w czasie założenia huty w pobliskich Żędowicach). Zawsze był to właściwie zakład przetwórstwa hutniczego, z dużą kuźnią i znaną wagonownią (podczas powstań śląskich zmontowano w niej 3 pociągi pancerne). W okresie międzywojennym hutę "Andrzej” wyposażono w nowoczesną walcownię, na wiosnę 1945 r. została ona jednak zdemontowana, a jej urządzenia, podobnie jak i podstawowe wyposażenie huty, wywieziono w głąb ZSRR. Huta w Zawadzkiem była w okresie powojennym czołowym producentem rozjazdów kolejowych i rynien przenośnikowych dla kopalń węgla, a w połowie lat 60 -tych XX w. została w niej zbudowana nowoczesna wytwórnia rur bez szwu, która pozostała do dziś głównym wydziałem produkcyjnym „Huty Andrzej”.

Obydwie huty nad Małą Panwią są obecnie Spółkami Akcyjnymi Skarbu Państwa, z którymi ściśle współpracuje szereg wyłonionych w toku ich prywatyzacji zakładów pomocniczych. W Zawadzkiem należą do nich spółki z o.o.: Przedsiębiorstwo Usług Technicznych „Andrzej”, „KolTram”, „, Koltrans” i „Rurex”. Do tradycji hutniczych nawiązuje w omawianym rejonie także bezpośrednio kilka innych zakładów, m.in. Fabryka Wyrobów Metalowych w Osowcu Śl. k/Turawy (powstała na bazie królewskiej fabryki założonej w 1785 r.), Fabryka Wyrobów Metalowych i Drzewnych w Zagwiźdżu w gm. Murów (na bazie dawnej, XVIII-wiecznej „Huty Kluczborskiej”) oraz spółka „Prempol Sp. z o.o.” w Ozimku, która wytwarza głównie konstrukcje metalowe różnych typów.

Do starych tradycji tutejszego hutnictwa szkła nawiązywały też dwa zakłady: huta szkła w Murowie, założona w 1755 r. przez potężny wówczas klasztor Norbertanek w Czarnowąsach k/Opola, była przez cały powojenny okres jednym z głównych producentów szkła taflowego (na jej bazie powstała ostatnio spółka akcyjna „WITROTERM”, produkująca poszukiwane na rynku budowlanym szyby zespolone) oraz huta szkła opakowaniowego w Jedlicach k/Ozimka, którą uruchomiono w 1959 r. w zabudowaniach po przedwojennej walcowni cynku.

$\mathrm{Z}$ bogatą historią tutejszego przemyshu drzewnego i papierniczego wiążą się również dzieje kilku do dziś istniejących zakładów. Na bazie starych Zakładów CelulozowoPapierniczych w Kaletach, powstałych w latach 1882-84 i funkcjonujących w swym tradycyjnym profilu do początku lat 90-tych XX w., uformowało się kilka spółek, w tym „SMOLLPAP Sp. z o.o. J.V.. największy w kraju producent serwetek i papierowych zastaw stołowych. Z dawnej Fabryki Papieru w Boruszowicach w gm. Tworóg, założonej w 1927 r., powstała spółka z o.o. PPHU „Cartex”, wytwarzająca papier, karton i bloki papierowe. Na miejscu starej Fabryki Tektury w Kolonowskiem powstała firma PACKPROFIL sp. z o.o., zaś teren i zabudowania po dawnym zakładzie suchej destylacji drewna w Fosowskiem czeka na inwestora. Samo Fosowskie (część m. Kolonowskie, w której w XVIII-XIX w. istniała tzw. huta Renarda) znane jest dziś przede wszystkim jako zurbanizowana osada kolejarska, związana z tamtejszym węzłem kolejowym. Na bazie bogactwa tutejszych lasów funkcjonują do dziś liczne tartaki, w tym 4 w samych Kaletach (największy z nich powstał ok. 1820 r. w zabudowaniach dawnej huty żelaza). Duży tartak, dziś Zakład Przemysłu Drzewnego OPDREW, S.A. istnieje też w Murowie, w sąsiedztwie wspomnianej huty szkła. Na północ od doliny Małej Panwi wykształcił się także od połowy XIX w., znany dziś nie tylko na Górnym Śląsku, ośrodek przemysłu drzewnego i stolarstwa meblowego w Dobrodzieniu. 
Innym rodzajem przemysłu, jaki od początku XX w. towarzyszył hucie „Małapanew”, były zakłady dziewiarskie w Dylakach k/Ozimka i Starych Budkowicach w gm. Murów. Do połowy lat 90-tych XX w. uzupełniały one strukturainie „męski” rynek pracy rejonu hutniczego.

Starym ośrodkiem hutnictwa żelaza był również Krupski Młyn nad Małą Panwią, w którym kuźnica była czynna do lat 70-tych XIX w. Dziś Krupski Młyn związany jest prawie wyłącznie z historią Zakładu Tworzyw Sztucznych „Nitron-Erg”, wyrosłego z powstałej w XIX w. wytwórni materiałów wybuchowych. Zakład ten przeżywa również ostatnio trudny okres restrukturyzacji, gdyż częścią swego procesu produkcyjnego był zawsze ściśle powiązany z górnictwem węgla kamiennego.

$\mathrm{Na}$ bazie dawnego i dzisiejszego uprzemysłowienia wyrosły na omawianym obszarze początkowo klasyczne „osiedla przemysłowe”. W 1954 r. prawa osiedla otrzymały Ozimek i Zawadzkie, w 1956 r. Kolonowskie i Krupski Młyn, zaś w 1958 r. do rangi takiej podniesiono, nie związany juź dziś z funkcją przemysłową Koszęcin. Najwcześniej prawa miejskie otrzymały jednak położone najbliżej Tarnowskich Gór Kalety (już w 1951 r.), podczas gdy inne nowe miasta utworzono dopiero w 1962 r. (Ozimek, Zawadzkie) i 1973 r. (Kolonowskie), z przekształcenia wcześniejszych osiedli. Obecnie są to typowe, monofunkcjonalne małe miasta przemysłowe, liczące po kilka tysięcy mieszkańców (Kolonowskie 4,1 tys., Kalety 9,0 tys., Zawadzkie 9,2 tys.), a jedynie Ozimek przekroczył 10,9 tys., mieszkańców. Stary ośrodek usługowo-handlowy Dobrodzień, który prawa miejskie uzyskał jeszcze w 1384 r., a tradycjami uprzemysłowienia sięga połowy XIX w., liczy dziś 4,5 tys. mieszkańców. Do rangi miast nie podniesiono natomiast dwóch pozostałych osiedli. Koszęcin w powiecie lublinieckim, jest dziś centrum gminy wiejskiej, a w tutejszym pałacu, dawnej rezydencji magnackiej, należącej w latach 1819-1945 do książęcej rodziny Hohenlohe-Ingelfinden, mieści się dziś siedziba znanego nie tylko w kraju Zespołu Pieśni Tańca "Śląsk". Także wspomniany wyżej Krupski Młyn w powiecie tarnogórskim, stał się po zmianach podziału administracyjnego kraju w 1973 r. siedzibą gminy wiejskiej. W swej fizjonomii jest jednak Krupski Młyn typowym osiedlem przemysłowym, z przeważającą zabudową pochodzącą z lat 50-tych XX w., powstałym wśród lasów nad Małą Panwią (por. Z. J. Kamiński, 1965).

Ważnym elementem infrastrukturalnym, łączącym dawne i współczesne zakłady hutnicze nad Małą Panwią jest linia kolejowa Tarnowskie Góry-Opole, oddana do użytku w 1858 r. Po II wojnie zmodernizowana i zelektryfikowana służy dziś jako dodatkowy szlak wywozu węgla z węzła tarnogórskiego, ale także umożliwia codzienny dojazd do pracy licznym jeszcze chłopo-robotnikom pracującym w hutach w Ozimku i Zawadzkiem, a także młodzieży wiejskiej, kształcącej się w tamtejszych szkołach średnich.

Swoistym akcentem, zamykającym prawie 250-letni proces uprzemysłowienia dorzecza Małej Panwi, może być ulokowanie na obydwu jego krańcach dwóch znaczących zakładów: w górnym odcinku tego dorzecza powstała bowiem w połowie lat 60-tych ubiegłego wieku Huta Cynku „Miasteczko Śląskie”, w pobliżu zaś ujścia Małej Panwi do Odry usytuowana jest Elektrownia „Opole”., Zlokalizowana w Brzeziu w gm. Dobrzeń Wielki elektrownia, budowana z przerwami od 1974 r., została włączona do krajowego systemu energetycznego dopiero w latach 1993-97. Dziś jest jednym z największych zakładów energetycznych w kraju, wyposażonym w nowoczesną, opartą na mokrej metodzie wapienno-gipsowej, instalację do odsiarczania spalin, zbudowaną przez niemieckie konsorcjum 
SHL-Klöckner INA. Historia tych zakładów wykracza już jednak daleko poza dzieje hutnictwa żelaza i skojarzone z nim działalności przemysłowe na terenie dorzecza Małej Panwi.

\section{Literatura}

H. Borek, 1989. Kolonizacja fryderycjańska na Górnym Śląsku w obliczu nazewnictwa miejscowego, „Studia Śląskie”. t. XLVII, s. 21-52.

S. Golachowski., 1965. Proces semi-urbanizacji w województwie opolskim, „Kwartalnik Opolski" r. XI, nr 2, s.11-31.

Z. J. Kamiński, 1965. Problemy rozwoju gminy Krupski Młyn - zagadnienia planowania przestrzennego, [w:] „Urbanizacja wsi na obrzeżach miejsko-wiejskich”, Katowice 1965, s. 127-137.

B. Kortus, L. Pakuła, 1998. Charakterystyka i ocena dorobku ośrodka krakowskiego w dziedzinie geografii przemysłu, [w:] „Dorobek polskiej geografii przemysłu w badaniach ośrodków akademickich", Warszawa-Kraków, 1998, s. 97-120.

T. Ładogórski T., 1949. Kolonizacja fryderycjańska na Ślqasku, „Przegląd Zachodni”, r. V, nr 5/6, s. 362-380.

S. Misztal, Z. Zioło, 1998. Wprowadzenie, [w]: Dorobek polskiej geografii przemystu, op. cit., s. 9-16.

J. Rajman, 1962. Rozwój ośrodków przemyslowych nad Malq Panwiq, Katowice, wyd. Śląsk.

A. Wajda, Zakład przemystowy w środowisku wiejskim (na przykładzie Huty „Małapanew” w Ozimku), Opole 1970. 